\title{
Aire: actante y metáfora en el delta del Níger de George Osodi**
}

\section{Juan Carlos Guerrero-Hernández ${ }^{* *}$}

La obra de fotorreporteros africanos ha seguido siendo estudiada como mero registro documental o como medio de representación de una identidad nacional poscolonial supuestamente definida. Este artículo se distancia de esa lectura y muestra que George Osodi articula el testimonio, el documento, la ficción y la imagen poética en "imágenes pensantes" que ponderan algunas dinámicas y tensiones ecológicas del delta del Níger, una de las regiones más bio- y etnodiversas, y de mayor explotación petrolera del mundo. Para ello, el artículo asume una aproximación formal y contextual a la serie Oil Rich Niger delta (2003-2007), que, en diálogo con elementos de la historia de esta nación y región petrolera y con referentes de la tradición oral, la poesía y la ecocrítica, entiende el aire como tema y actante en una amplia red ecológica de humanos y no humanos, y como recurso metafórico con el que Osodi indaga algunas de las complejas tensiones ecológicas y una nueva cosmología del delta. Con énfasis en el aire como metáfora y como elemento actante, se muestra cómo Osodi rompe con la idea de que el fotorreportaje africano es principalmente antropocéntrico y cómo trabaja meticulosamente conexiones entre humanos y no humanos parte de un rico ensamblaje social en el que el fotógrafo da dignidad a actantes y actores.

Palabras clave: ecología, actantes, fotografía africana, delta del Níger, cosmología. doi 10.11144/javeriana.mavae15-2.aaym

Fecha de recepción: 10 de noviembre de 2019

Fecha de aceptación: 17 de marzo de 2020

Disponible en línea: 1 de julio de 2020

Artículo de investigación. Producto parcial del * proyecto de investigación registrado bajo el número PR.3.2016.3087 y apoyado por la Vicerrectoría de Investigaciones de la Universidad de los Andes.

**

Doctor en Historia del Arte por la Stony Brook University, magíster en Filosofía por la Universidad Nacional de Colombia, magíster en Ingeniería Eléctrica por la Universidad de los Andes.

ORCID:0000-0001-7064-1450

Correo electrónico: juan.guerrero.hernandez@gmail.com 


\section{Air: Actant and Metaphor in George Osodi's Niger Delta}

The work of African photojournalists is still assumed as mere documentary record or as a means of representing a supposedly defined post-colonial national identity. The article distances itself from that reading and shows how Osodi articulates testimony, document, fiction and poetic image in 'pensive images' that ponder some ecological dynamics and tensions of the Niger delta, one of the most bio- and ethno-diverse and oil-exploited regions in the world. To this end, the article assumes a formal and contextual interpretation of the series Oil Rich Niger Delta (2003-2007) which, in dialogue with elements of the history of this oil-producing nation and region, and with references from oral tradition, poetry and ecocriticism, understands the air as a subject and actor in a broad ecological network of humans and non-humans, and as a metaphorical resource with which Osodi investigates some of the complex ecological tensions and a new cosmology of the Delta. Emphasizing on air as both a metaphor and acting element, it shows how Osodi breaks with the idea that African photojournalism is primarily anthropocentric, and how he meticulously works with connections between humans and non-humans as part of a rich social assemblage in which the photographer gives dignity to actants and actors.

Keywords: Ecology, actants, African photography, Niger Delta, cosmology.

\section{Ar: actante e metáfora no delta do Níger por George Osodi}

0 trabalho dos fotógrafos africanos continuou a ser estudado como um mero registro documental ou como meio de representar uma identidade nacional pós-colonial supostamente definida. 0 artigo se distancia dessa leitura e mostra que 0 sodi articula o testemunho, o documento, a ficção e a imagem poética em 'imagens pensantes' que refletem algumas dinâmicas e tensões ecológicas do delta do Níger, uma das regiões mais bio e etnodiversas, e a maior em exploração de petróleo do mundo. Para isso, 0 artigo pressupõe uma abordagem formal e contextual da série Oil Rich Niger delta (2003-2007) que, em diálogo com elementos da história desta nação e companhia petrolífera e com referências na tradição oral, poesia e a eco crítica, entende 0 ar como sujeito e agente em uma ampla rede ecológica de humanos e não-humanos, e como recurso metafórico com o qual Osodi investiga algumas das complexas tensões ecológicas e uma nova cosmologia do delta. Enfatizando o ar como uma metáfora e como um elemento de atuação, é mostrado como Osodi rompe com a ideia de que o fotojornalismo africano é principalmente antropocêntrico e como ele trabalha meticulosamente as conexões entre humanos e não-humanos, parte de um rico encaixe social na qual o fotógrafo dá dignidade a atores e atores.

Palavras-chave: Ecologia, atores, fotografia africana, delta do Níger, cosmologia. 
$>$ George Osodi (Port Harcourt, 1974-) es un fotorreportero nigeriano, nativo del delta del Níger, que a finales de la década de 1980 comenzó a trabajar como freelance, vendió fotografías para periódicos locales y para la Associated Press, en 2004 fue reconocido como el fotoperiodista africano Fuji, y desde entonces ha expuesto en galerías. Su trabajo y el de otros fotógrafos africanos hacen parte de una rica producción que desde 1999 se ha interesado por abordar los efectos de la minería, de la extracción de petróleo y de la quema y amontonamiento de residuos tecnológicos. Estos y otros trabajos fueron recogidos por la Bienal de Fotografía Encuentros de Bamako (también conocida como la Bienal Fotográfica de Bamako) en su duodécima versión titulada "Por un mundo sostenible".

A pesar de los reconocimientos que Osodi y contemporáneos suyos como Jide Adeniyi-Jones y Andrew Esiebo han recibido, la atención de la crítica y de la academia sigue siendo exigua y superficial. Esta situación se debe no solo al amplio desconocimiento que aún hay de la producción en cuestión en nuestro medio local, sino también a la asunción acrítica y generalizante de que estos trabajos se limitan a ser registros documentales de una realidad ( $y$, en este sentido, estarían abocados a la función primaria del registro indexical) o a ser medios de representación y construcción de una identidad nigeriana definida (Paoletti 2009, 80).

La propuesta de este artículo es complicar tales asunciones y entender las imágenes de Osodi en su serie Oil Rich Niger Delta (2003-2007) como producto de operaciones entre elementos y referentes visuales, históricos, políticos y culturales, como imágenes que articulan el testimonio, la ficción, lo sido y lo que puede ser, y como imágenes histórico-poéticas pensantes que entretejen y complican la metáfora y el registro, lo natural y lo artificial, lo humano y lo no humano. Y qué mejor para ello que detenerse en el aire que semeja forzarnos continuamente a referirnos a otras cosas y a las superficies de contacto (p. ej., la superficie del agua como "interfaz" entre aire y agua) para visibilizarlo. El aire es esquivo testimonio y difícil metáfora, "elemento" natural y social, humano y no humano, histórico y poético, y esquivo objeto de nuestras acciones y actante que "modifica un estado de cosas" aun si por momentos carece de figuración evidente (Latour 2005, 71). El aire nos da para pensar algunas de las complejas tensiones ecológicas del delta del Níger en la obra de Osodi. En esta dirección, este artículo se divide en tres partes. Cada una de ellas perfila el aire como actante y metáfora de una nueva cosmología del delta, en atención al aire bajo la figuración del ruidoso gas en combustión, bajo su callada cotidianidad en el paisaje circundante o bajo la figura del ave. 


\section{Gas en combustión}

La República Federal de Nigeria es una de las mayores exportadoras de petróleo a nivel mundial. Sus reservas petroleras calculadas en 2018 eran de un poco menos de 40000 millones de barriles (OPEC 2019), y la extracción de petróleo durante el periodo en el que Osodi produjo la serie fue de cerca de 2,1 millones de barriles por día. El desarrollo de Nigeria como potencia petrolera comienza después de una guerra civil (1967-1970) causada por las tensiones entre grupos étnicos dominantes. En 1966, seis años después de la independencia, hubo dos golpes de Estado consecutivos. Los líderes del segundo golpe buscaron darle mayor fuerza al Gobierno federal y para ello optaron por fracturar en Estados las tres grandes regiones tradicionalmente asociadas a los territorios de influencia de las tres grandes etnias Yoruba, Igbo y Hausa-Fulani. Frente a este fraccionamiento, los Igbo, el grupo étnico dominante en la región de Biafra que incluye el delta del Níger, decidieron declarar su independencia. La respuesta de los golpistas fue inmediata con una avanzada militar apoyada por fuerzas y países extranjeros, que causó el exterminio de más de 30000 lgbo en los más de dos años de duración del conflicto. Con el final de la guerra, una seguidilla de juntas militares aumentó de manera drástica la extracción y exportación del petróleo y gas, que discursivamente los convirtió en "elementos vitales" cuyas "bendiciones" lograrían minimizar diferencias étnicas y superar el "tribalismo" bajo una imaginada nación.

No sobra decir que esta nación no ha de ser asumida sin más como aquella de la que hablara Benedict Anderson, es decir, como una nación estrictamente originada y desarrollada como resultado de la modernidad y del colonialismo (Bhabha 1990). De hecho, en un esfuerzo por desmarcarse del colonialismo y por plantear un "modelo alternativo del Estado nación poscolonial [...] que revisaba la suposición de que los Estados nación poscoloniales se fundan en Estados previamente colonizados tallados o ensamblados por imperios europeos" (Wu 2016, 175'), el nacionalismo nigeriano se entendió como movimiento político, "construcción cultural" y proyecto creativo que extraía sus energías de "fuentes indígenas" (Loomba 2005, 159). En este sentido, en un problemático y a la vez significativo giro, el nacionalismo estatal asumió imágenes "excesivamente metafóricas" para la construcción de una nación (Bhabha 1990, 1), y presentó y celebró el petróleo como fluido vital y dador de vida del nuevo cuerpo nacional (Apter 2005, 23). El petróleo sería la sangre indígena extraída por una emergente civilización petrolera nigeriana que alimentaría y en la que se manifestaría la cultura nacional.

Ahora bien, el tropos del petróleo como sangre de la nación no puede entenderse completamente sin comprender que se asumió tanto en el discurso interno como hacia el exterior. De hecho, fue proyectado internacionalmente en una jugada que buscaba poner a Nigeria como ejemplo mundial de una nueva cultura petrolera que habría de exportarse como el petróleo. Aquí es necesario recordar que en 1977 la junta militar organizó y llevó a cabo el Festac '77, un gigantesco festival cultural apoyado por la Organización de las Naciones Unidas para la Educación, la Ciencia y la Cultura (Unesco), y posiblemente el más grande en la historia moderna del planeta, con un costo mayor a tres billones de dólares de la época (De Gouveia 2014). El primer objetivo del festival era "asegurar el resurgimiento, la propagación y la promoción de la cultura negra y africana, así como los valores y la civilización cultural negra y africana" (Festac '77 Visitors Guide to the Festival 1977). Festac '77 buscó distanciarse del esencialismo de las exhibiciones coloniales y de los nacionalismos étnicos, culturales y religiosos presentes en muchas luchas poscoloniales en África. Y aunque se alimentó parcialmente de los movimientos de la Négritude (desarrollado por intelectuales francófonos de la diáspora africana en la década de 1930) y del Panafricanismo (desarrollado por la diáspora africana en el continente americano y el Caribe en la década de 1960), no obstante presentaba una "visión nigeriana del mundo negro y africano" (Apter 2005, 3). Se buscaba superar 
Figura 1. Philip Gaunt, Festac '77 - Festival de Lagos. 1977.

Fuente: Unesco TV/Nigerian National Broadcasting Commission.

$\Lambda$

$\Lambda$ las diferencias culturales también fuera de los límites nacionales, en una modernidad globalizada del mercado petrolero, en la que este sirvió de "modelo expansivo de equivalencia racial e inclusión" (3). En otras palabras, el festival buscó inaugurar una suerte de cosmopolitanismo africano y negro de carácter nigeriano, con el que este país tendría la función de reescribir la historia en línea con algunos ideales del Movimiento de Países No Alineados (en particular sus conferencias de 1976 y 1979). ${ }^{2}$ Si el continente negro había sido origen biológico de la especie humana, ahora la emergente civilización nigeriana, entendida como "la combinación de hechos y fenómenos sociales, estructuras y valores que caracterizan a una sociedad determinada" (Senghorel 1977, 12), sería la que encarnaría la cultura africana y negra (i. e., "su espíritu") y origen de un nuevo y más equitativo orden global.

Por esto mismo, no son casuales dos decisiones clave en el modo como el festival se presentó. El logo del certamen fue la bella máscara de la Reina-Madre Idia, ejemplo de la maestría del trabajo artístico del Imperio de Benín (actual Nigeria), y reconocida como una de las más exquisitas obras de origen africano hasta entonces conocidas. Esta joya hecha en marfil, robada por los británicos en la vergonzante expedición punitiva de 1897, simbolizaba con su tocado-corona el poder de la reina Idia para canalizar el flujo del comercio internacional a favor de su hijo (LaGamma 2012, 29). Sin duda, la escogencia de la máscara de "la primera mujer en ir a la guerra" (Kaplan 2008, 527), que por cierto ya estaba presente en los billetes nigerianos desde 1973, sugería en 1977 el poder de la tierra-madre nigeriana para nutrir y conducir el petróleo como poder comercial global nigeriano. Debido a que los británicos no prestaron la máscara (muy en línea con su actitud de rechazo de la convención de 1970), ${ }^{3}$ el Gobierno nigeriano contrató a un artista para que hiciera el logo. Desde entonces la máscara en manos británicas se conoce en África bajo el nombre de la "máscara de Festac '77", apelativo que evidencia una inversión de tipo decolonial muy significativo y el profundo impacto que sigue teniendo el festival en el imaginario de África y de Nigeria.

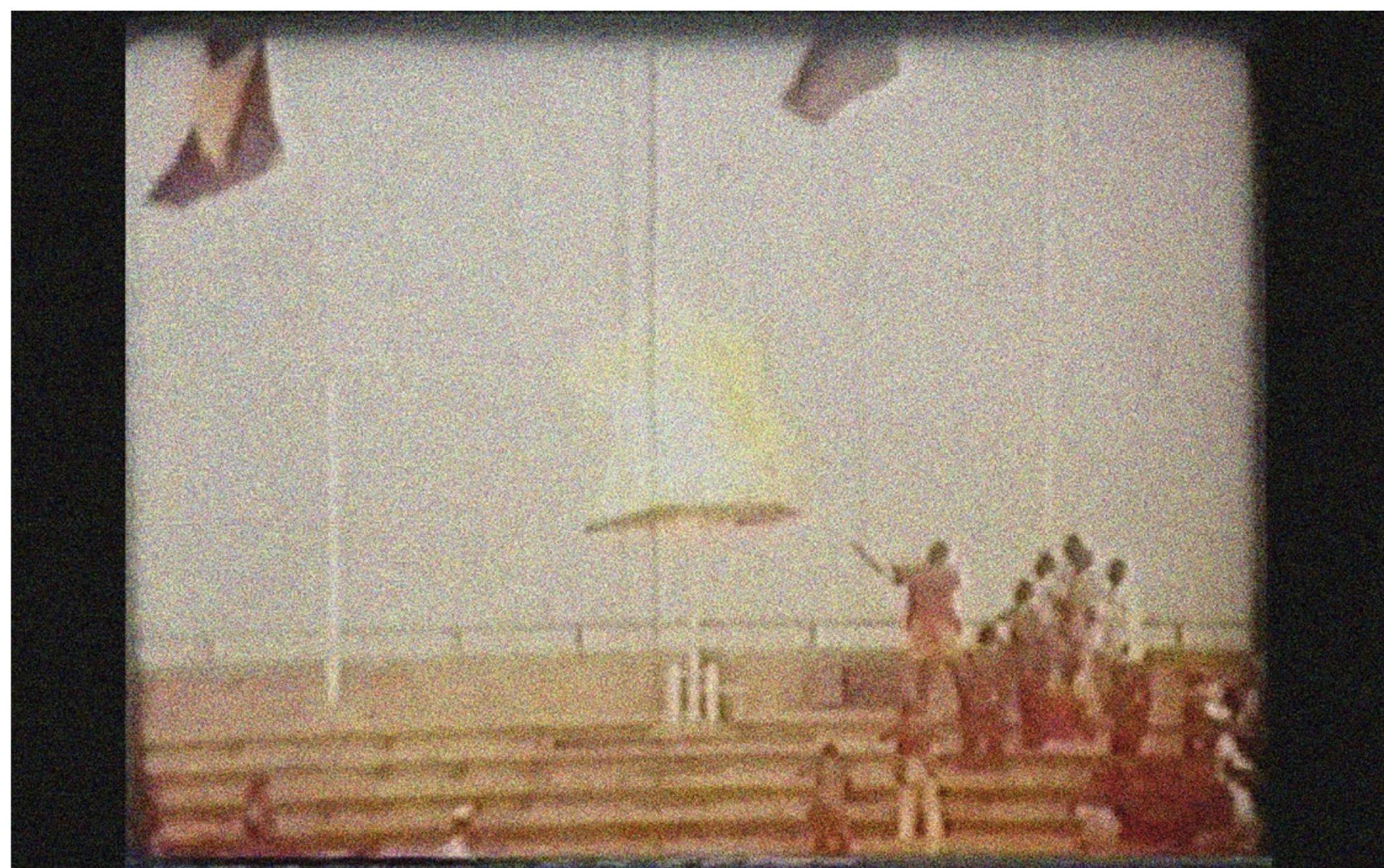


La segunda decisión impactante a nivel nacional e internacional fue que el festival se inauguró como si se tratase de unos juegos olímpicos en el Estadio Nacional de Lagos con la participación de 48 países de los 75 invitados (Colombia recibió la invitación pero no participó). Esta decisión no es secundaria, ya que en 1976 Nigeria y otros 25 países africanos boicotearon los Juegos de Montreal porque el comité organizador había invitado a Nueva Zelanda, cuya selección de rugby acababa de jugar con la selección de Sudáfrica excluida por la política del apartheid. En este sentido, el Festac '77 fue como los juegos negros y africanos, y celebró la hermandad en convivencia. Y, en este sentido, no menos importante es que el evento central de la inauguración fue el encendido de la llama "olímpica" a manos de un sacerdote changó. Esa fluctuante lengua de fuego visibilizó el petróleo como elemento vital, como sangre indígena nigeriana cuyo espíritu sagrado alimenta nueva libertad y justicia ${ }^{4}$ cosmopolita africana y negra (figura 1). No en vano hay una diciente expresión que cierra el documental oficial del Festac '77: si bien al final del festival la lengua de fuego se apagará, no obstante, "el espíritu de la llama del festival arde y el continente negro se ha convertido en luz" para el mundo (Gaunt 1977).

El festival evidenció que la petromodernidad de la década de 1970 en Nigeria fue un todo "espectáculo" (Wu 2016, 180). Pero este espectáculo, como lo sugiere poéticamente las siguientes dos fotografías de la serie de Osodi, continua y es el de una modernidad transformadora del paisaje y la cultura nigeriana. Se trata del espectáculo que ha involucrado la instalación de gigantes llamaradas de gas en combustión que han transformado el aire, los sueños,

Figura 2. George Osodi, "Gas Flare at Night". 2006

Fuente: George Osodi, https://georgeosodi. photoshelter.com/index. el espacio, el tiempo y la sociabilidad de la gentes del delta del Níger. 


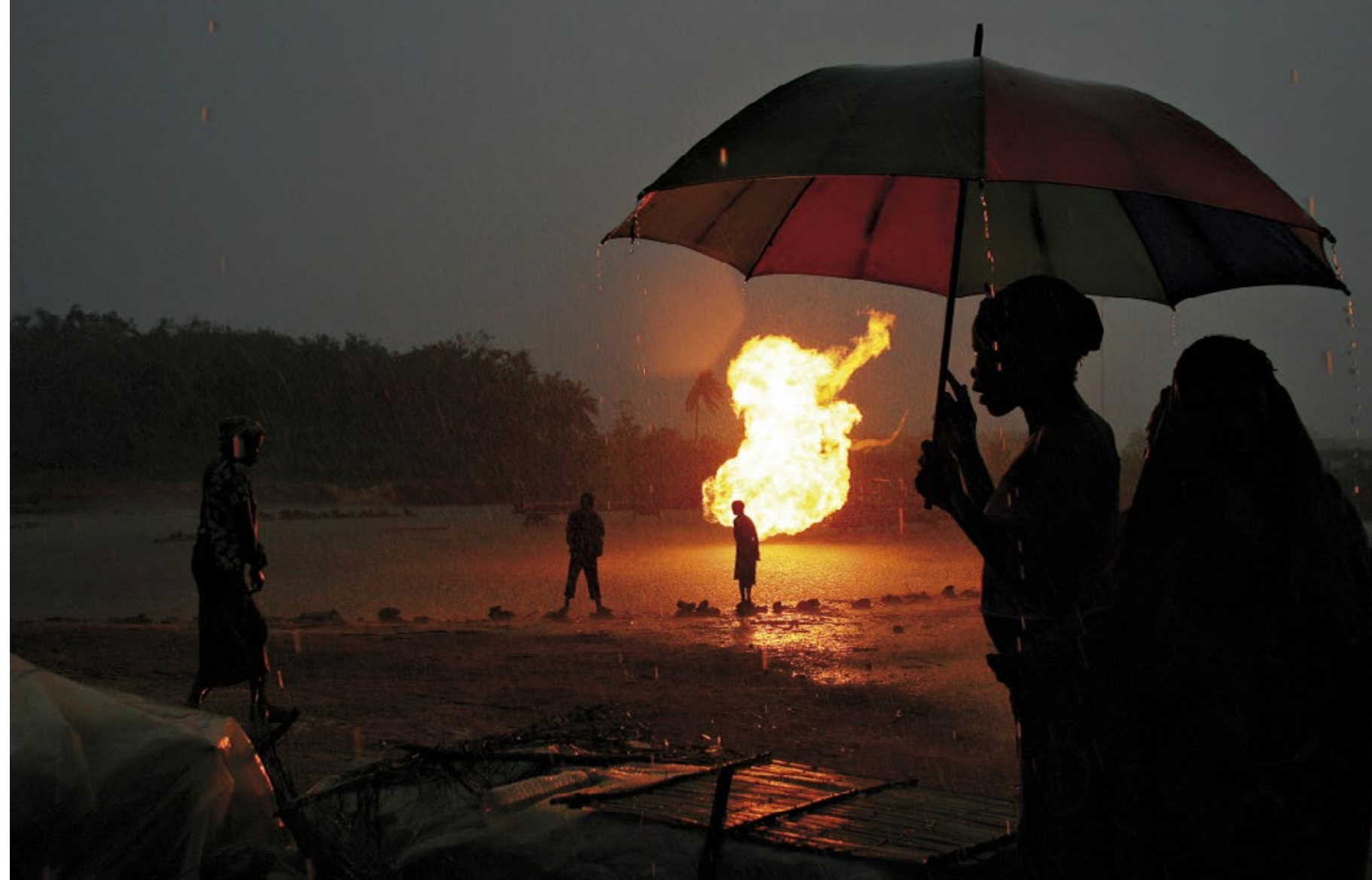

Fuente: George Osodi https://georgeosod. photoshelter.com/index.
La húmeda noche nigeriana en que las siluetas eran consumidas por la oscuridad o en que la luz blanca de la luna iluminaba las calles del pueblo o se colaba por ventanas, el follaje del techo o del campo para espiar a los amantes ha sido transformada por una luz y atmósfera anaranjada (figura 2). Desde la esquina superior izquierda, una línea virtual de tres cables de transmisión de energía eléctrica nos guía dentro de la espesa atmósfera para anclarse en un poste. Y desde la esquina inferior izquierda una franja definida por la carretera nos guía hasta el reflejo del poste en la mitad del corredor vial. Línea y franja definen una región de interés. Vemos, primero, a la izquierda, un establo con semovientes, y un par de largas sombras sobre la tierra sin pasto. En el centro, vemos la figura de un hombre que parece haber acabado de bajarse de la bicicleta o estar a punto de montarse en ella. El paraguas, en el que los tres colores básicos son conjurados con una paleta anaranjada, se inclina como si el hombre quisiera ya no protegerse de la lluvia, que parece haber amainado, sino del potente sol nocturno que inesperadamente se manifiesta con mayor fuerza iluminando el poste y la vegetación al lado suyo. Parece como si una potente luz (¿un rayo?, ¿Changó?) hubiese atravesado la espesa cobertura naranja de la lluvia y de la noche, y hubiese trastocado el orden inmemorial de los ciclos de tiempo (día y noche) reafirmando con ello la atmósfera y la noche "surreales".

En otra fotografía (figura 3) de la serie, vemos al menos cinco personas bajo la lluvia. Dos de ellas, presumiblemente mujeres, aparecen en el primer plano bajo un paraguas similar al anterior. Sobre la tierra, a la izquierda, observamos una esterilla y plásticos; y un poco más allá, otra mujer que camina bajo la lluvia en dirección contraria a la dirección de observación de la mujer que sostiene la sombrilla. Luego, en un tercer plano, vemos dos figuras (un hombre y una mujer) que, como la mujer a la derecha, parecen absortos en el fuego. La llamarada es el foco de atención fotográfico y centro virtual del accionar o silencios de estas personas. La potencia energética asociada al petróleo (que al ser extraído trae consigo gas que ha de ser quemado cuando no puede ser usado (Thurber 2019)) abre un claro en la noche y en el paisaje, define una nueva "ágora" en una región donde se respira el aire poluto de la petronación. Esta imagen nos recuerda que a veces no reparamos lo suficiente en que el fuego y el aire, y en este caso el gas consumiéndose, "antes que un ser natural es, sobre todo, un ser social" (Bachelard 1966, 22). 
En este sentido, el escritor nigeriano Helon Habila cuenta en su novela Oil on Water:

Los aldeanos festejaron durante semanas. Consiguieron su fuego anaranjado [...] Ardía de noche y de día, y ahora los aldeanos no necesitaban velas ni lámparas, todo lo que tenían que hacer por la noche era abrir de par en par las puertas y ventanas, y así todo estaba iluminado. Esa luz pronto se convirtió en la plaza del pueblo. Por la noche, los hombres y las mujeres se ponían de pie frente a él, perdidos en el asombro, durante horas, simplemente mirando hasta que sus ojos se humedecían y sus cabezas se mareaban. La reunión de la aldea, que solía tener lugar temprano por la mañana los sábados en una de las aulas de la escuela, ahora se realizaba por la noche bajo el fuego anaranjado. $(2011,152)$

En ambas fotografías, las figuras fantasmagóricas (fantasmagoría: aparecer/aparición en el ágora) de estas noches y atmósferas "surreales" son figuras ambiguas de la vigilia y del sueño. Como en los dos primeros versos del poema Night Rain del también nigeriano John Pepper Clark (2020), esas contrastantes figuras pareciera invitarnos a cantar "What time of night it is / I do not know". ¿Qué hora es, de dormir, de meditación e introspección, de amor, de conversación, de trabajo...? Habila continúa: "Alrededor de ese resplandor se desarrolló un mercado nocturno, y todas las noches las mujeres traían sus productos. Algunos vinieron de las aldeas vecinas, compraron y vendieron, instalaron hogares portátiles de hierro y akara, y pescados fritos, que vendieron a niños felices bajo ese fuego" (2011, 152).

El tiempo social de las noches y de los días, reales o imaginados, ya no es el mismo. La fluctuante y ruidosa lengua de fuego afirma una nueva justicia que también revela, por así decirlo, el lado oculto de aquella celebrada en el Festac '77. Se trata de una justicia económica y de un espíritu ansiado de libertad que promete una liberadora enfermedad y una enferma libertad. No en vano, en Oil on Water, un aldeano le dice al doctor Dagogo-Mark: "No estoy enfermo. Solo soy pobre. ¿Me puede dar medicina para eso? Queremos ese fuego que arde día y noche " (Habila 2011, 152). Estas personas están marginadas y enfermas, pero, igualmente, llenas de la vitalidad de la promesa del flamante y contaminante gas del petróleo que respiran. Para ellos, parece no haber otro remedio que participar en la petroeconomía, no otro remedio que el no remedio de esa economía, y no otra justicia que la in-justicia como paradójico ensamblaje entre querer un remedio y no estar enfermo, entre el querer enriquecerse y la vertiginosa eliminación de esa riqueza, entre respirar la promesa de vida, y el consumirse de esa vida misma. Ya decía el poeta nigeriano Remi Raji que "el aire que respiramos es un bramido / de fuego, lava y otros suicidios reprimidos durante mucho tiempo" $(2005,37)$. ¿No es esto algo que una de las más bellas fotografías (figura 4) de esta serie nos sugiere y en la que el hábil uso del foco y de la profundidad de campo muestra a un niño tomando agua y siendo devorado/contenido por la gran lengua de fuego de gas en combustión? 
崖

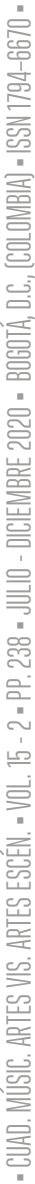

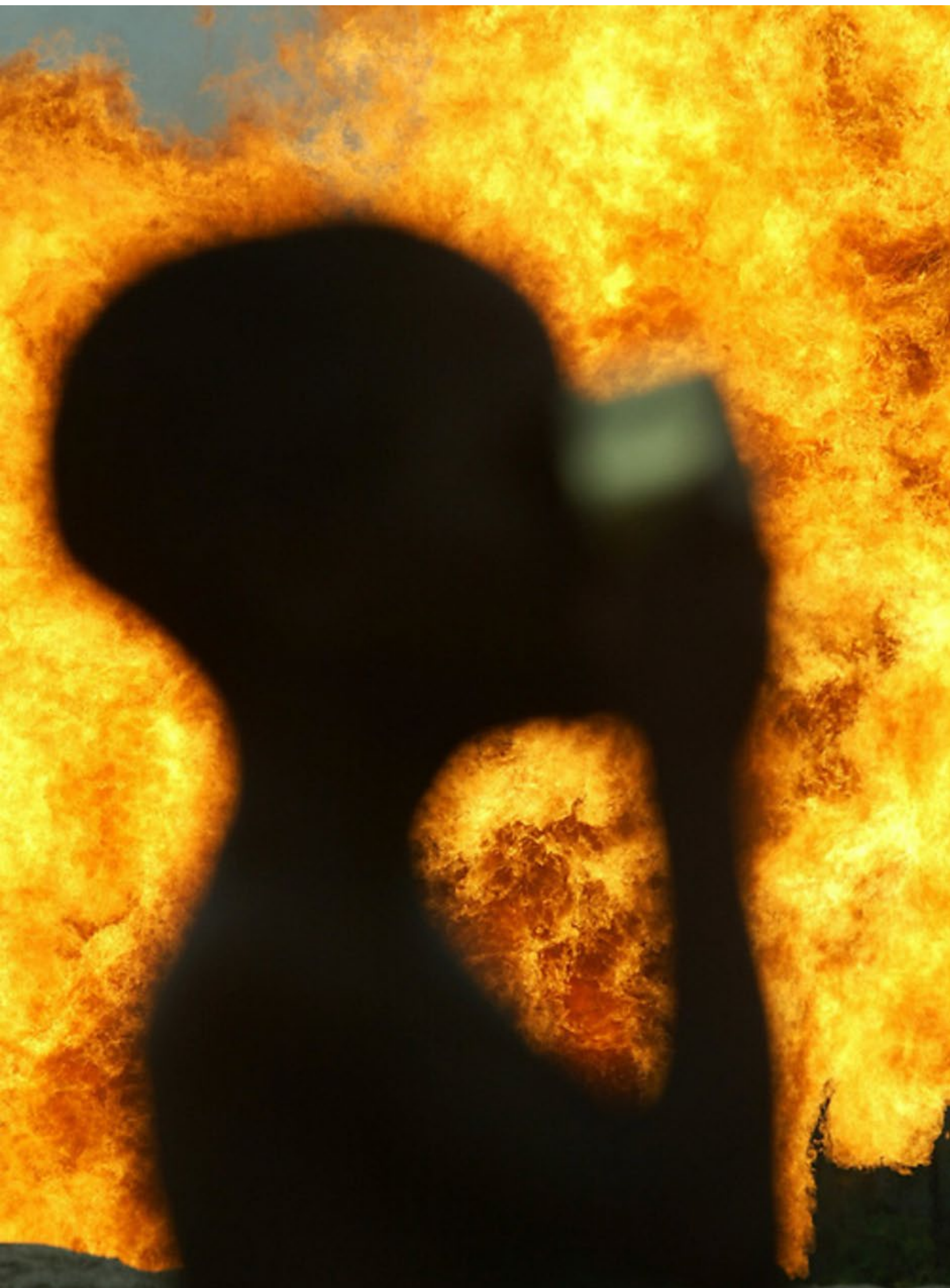

$>>$ 


\section{Cosmología}

Como es fácil imaginar, la infraestructura petrolera en Nigeria es gigante. En 2008, había más de trescientos campos petroleros insertados en medio del delta del Níger (más exactamente en los estados de Delta, Bayelsa y Rivers, la frontera sur del estado de Edo y las costas del estado de Akwa lbom), una de las regiones de "mayor diversidad biológica en el mundo" (Iheka 2018, 89). Igualmente, ya había más de $7000 \mathrm{~km}$ de tuberías que competían con los miles de canales que tiene el delta en sus casi 70000 km2, y más de 5000 pozos, 10 terminales de exportación, 275 estaciones de flujo, 10 plantas de gas y 4 refinerías (figura 5) (Watts 2008, 34), todas en una región que "alberga a más de cuarenta grupos étnicos" (Iheka 2018, 89), entre ellos, las minorías Ogoni, lyo y Ngwa. Semejante estructura de un complejo teatro-espectáculo económico-político petrolero es parte de una entramada red de cuerpos (humanos y no humanos), materiales de un nuevo paisaje, y una nueva vida y cosmología del delta.

En otras de las fotografías de Osodi (figura 6), vemos en un plano intermedio una estructura que parece emerger en la mitad de una charca de petróleo y agua estancada, causada por fuga de petróleo y lluvia tropical. Vemos, igualmente, en un siguiente plano, a tres hombres que caminan cerca del borde. Al fondo están las nubes y el paisaje de lo que parece ser una sabana. A la izquierda hay una palma. Sobre la superficie de la charca se reflejan las nubes, los hombres y la estructura. El fotógrafo se ha encargado de registrar la estructura de una manera frontal que solo erróneamente podría asumirse como meramente documental. El uso de un gran angular introdujo una deflexión del horizonte y una visión distinta a la de la visión humana. Osodi introdujo también un juego de reflejos que, más que registrar lo hasta aquí listado, propone un desdoblamiento en que estructura, hombres y palma son fotográficamente dispuestos como fantasmagorías en la superficie reflectante.

Figura 5. Posos petroleros (polígonos en blanco) llamaradas (puntos rojos) en el delta del Níger.

Fuente: NOSDRA, https:// nosdra.gov.ng/.

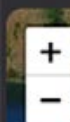

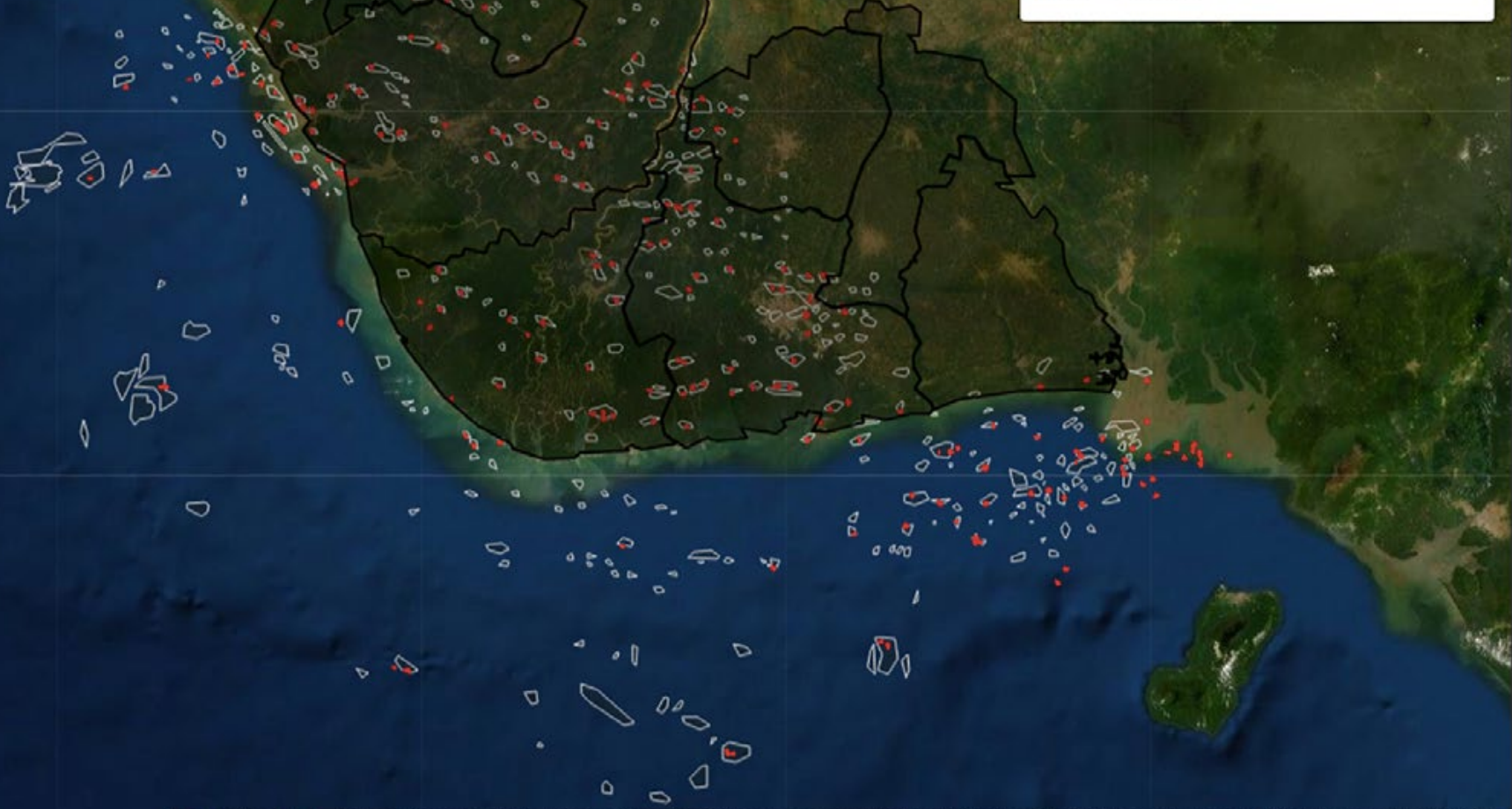


los tótems sufrieron con los cambios sociales, por ejemplo, con la esclavitud y la violencia bajo el reino de Benín, así como por fuerzas económicas o intereses de legitimación entre los lgbo en el delta del Níger (Oriji 2009). Y si bien se puede decir que con los cambios culturales, económicos y tecnológicos de hoy y la entrada de creencias (p. ej., la cristiana) y objetos de consumo de culturas foráneas se ha hecho que los tótems ancestrales comiencen a perder parte de su protagonismo y sentido tradicional (Peter 2007), también es cierto que el "tótem" de la fotografía puede dar cuenta y a la vez ayuda a configurar y vislumbrar una nueva cosmología asociada al petróleo.

Esto es lo que de una manera sutil pero contundente propone Osodi en la fotografía en cuestión y en una segunda (figura 7) en la que pasamos de la fotografía tipo "paisaje" a una fotografía tipo "retrato" dado el registro de la estructura en primer plano. Esta estructura se levanta también en medio de un estanque de petróleo y agua tan oscuro que refleja el paisaje casi a la perfección. La mujer de vestido colorido y la parte superior del tronco central de la estructura "dialogan" formalmente en sus diferencias. Y la sugerida pero incompleta simetría (vertical y horizontal) de la estructura de tres brazos se complementa con la mujer en el plano del fondo que sostiene su bicicleta, como si el ensamble mujer-bicicleta sugiriese ser el cuarto brazo que falta en la estructura. No en vano el reflejo del ensamble mujer-bicicleta en el estanque es ocultado por el brazo inferior izquierdo de la estructura.

En un bello juego virtual de simetrías, reflejos y reemplazos, Osodi no solo nombra y registra el complejo ensamblaje de válvulas de control y paso conocido en ingeniería de petróleos como "árbol de Navidad", y que es la parte visible del pozo empleada para la extracción de petróleo o gas, o para inyectar aire o agua cuando desde allí se busca forzar e incrementar

Figura 7. George Osodi, Christmas Tree II. 2007.

Fuente: George Osodi, https://georgeosodi. photoshelter.com/index. la extracción en otro pozo aledaño. El término "árbol de Navidad" también nombra y evoca

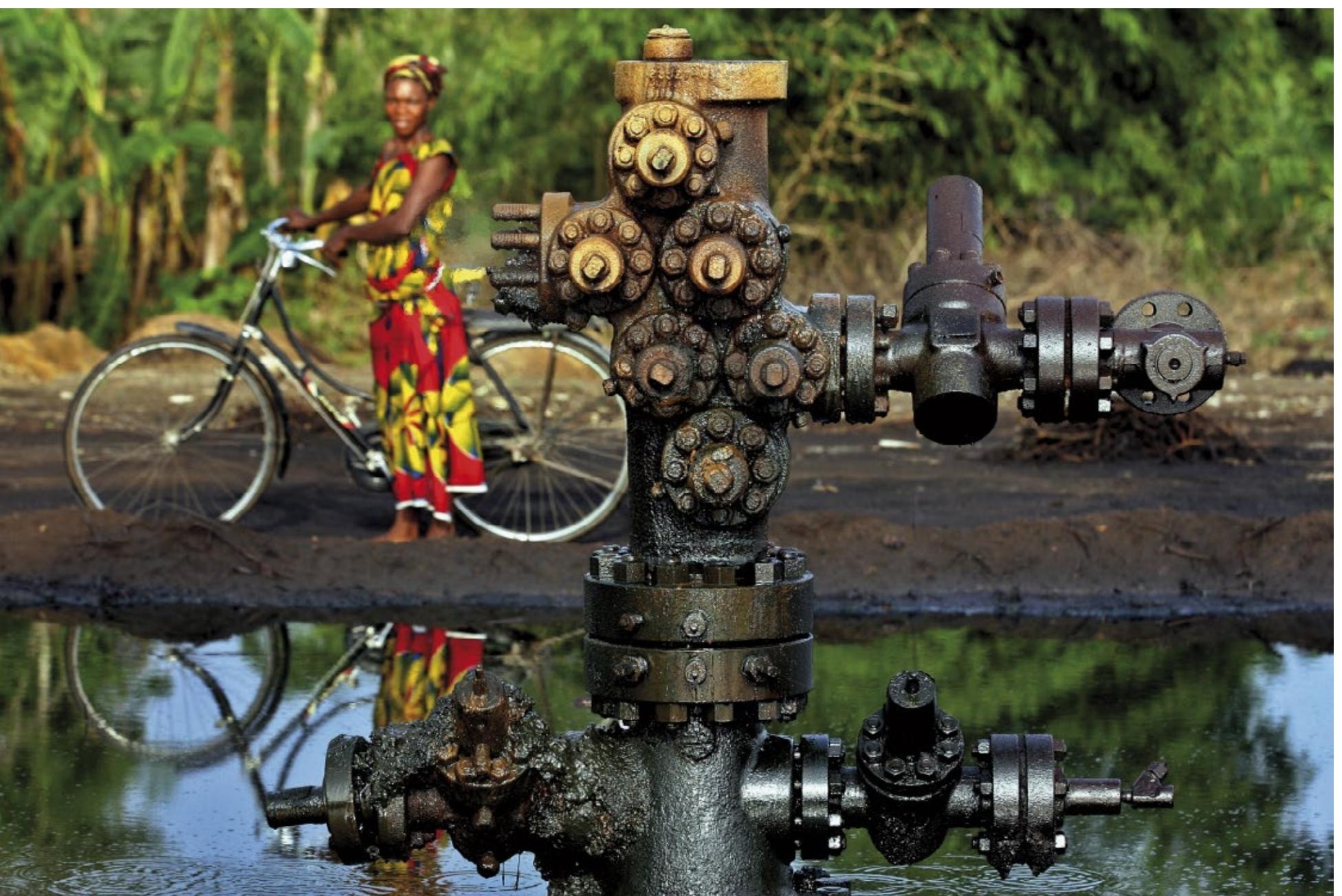


Figura 8. George Osodi, "Ogoni Spill Oil". 2004.

Fuente: George Osodi, https://georgeosodi. photoshelter.com/index.

$\Lambda$

$\Lambda$ "árboles" y "tótems" que catalizan la imaginación de una pertenencia a y apropiación de una modernidad global, dan cuenta de la colonialidad (p. ej., la llegada del cristianismo), catalizan fabulaciones colectivas de una promesa por venir ("natividad", "nueva alianza"). Y qué decir de la bicicleta que, como bien lo sugiere la bella película La vie sur terre (1998) del maliense Abderrahmane Sissako, apunta a que el paisaje y la temporalidad de la vida diaria en/sobre la tierra de África occidental están llenos de y han sido transformados por "centauros" o ensambles (ser-humano y bicicletas) que han llegado a los campos con la cultura del petróleo y que, como la suave brisa, se desplazan moderada y cadenciosamente por senderos y pueblos, transportándose y transportando víveres, amores, soledades, cartas y esperanzas.

Así pues, esta fotografía no debe ser reducida a una lectura inmediata de mero reportaje. Ella revela un poético ensamblaje virtual donde las cosas dejan de ser meras cosas y se muestran como "actantes" que operan y nos interpelan tanto a nivel de su función habitual como de su función formal en la imagen (Hawkes 1977, 89). En esta bella composición, Osodi creó un ensamblaje en el que el "tótem" es estructura que media nuestra percepción del ensamble mujer-máquina, y permite que complejidades internas del mundo real y virtual de una petrocosmología nigeriana se vuelvan visibles (Bueger y Stockbruegger 2017, 30). Una petrocosmología que involucra tanto las espectaculares y ruidosas lenguas de fuego como las menos espectaculares composiciones de una silenciosa cotidianidad.

En este sentido, Osodi perturba la crítica planteada en 2017 por lheka de que en el fotorreportaje africano reina un "enfoque antropocéntrico", también presente en la literatura ecocrítica, y en el que se habla o registra a "personas que se vuelven pobres por la violencia ecológica" $(2018,163)$; idea que por cierto resuena con la que ya hace años en Colombia se planteó bajo

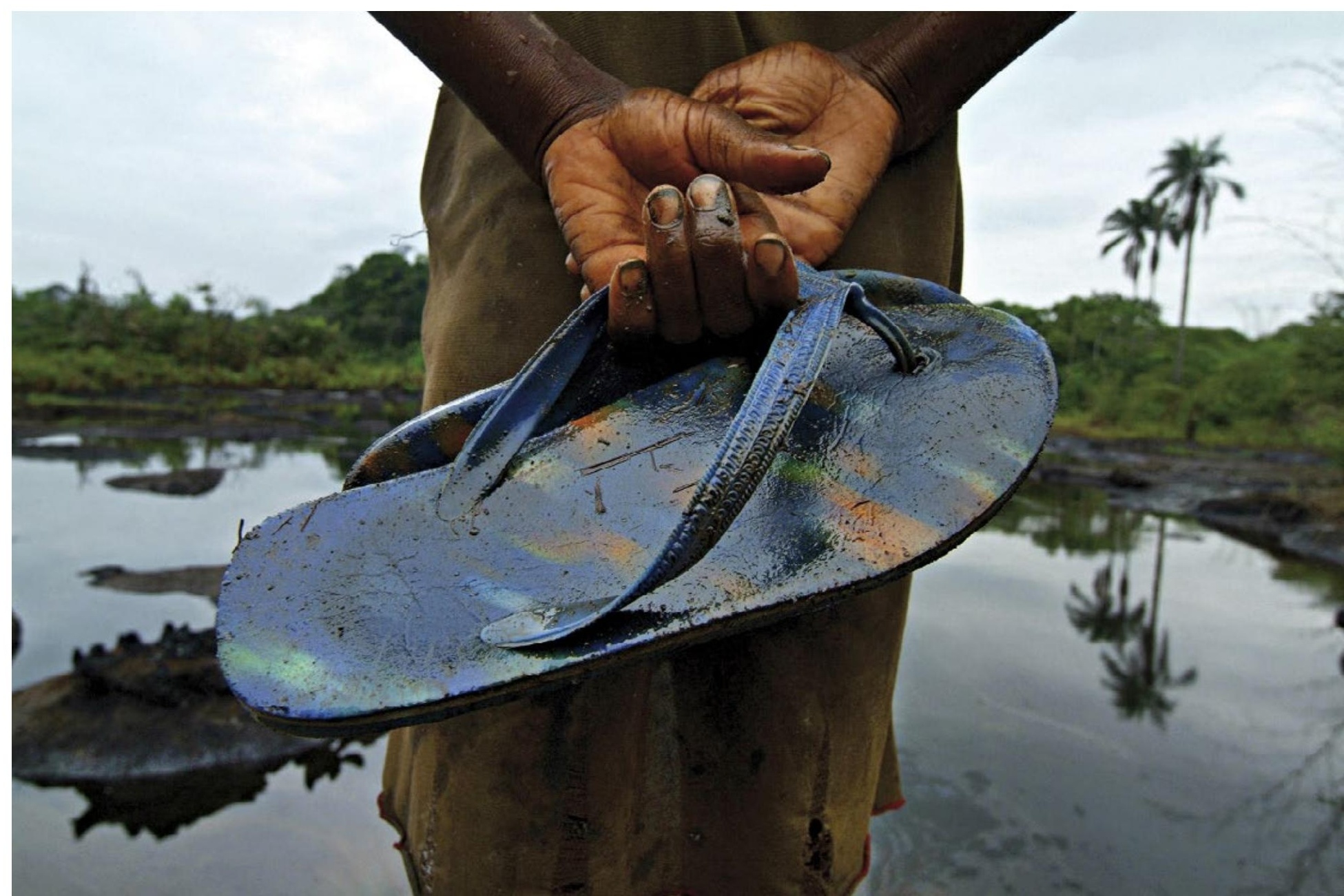


el término "pornomiseria". Es cierto que Osodi no deja de producir fotografías que dan cuenta de la pobreza y violencia que, podría decirse, es inevitable ignorar en el delta del Níger. Pero también es cierto, como se muestra aquí, que lo hace planteando la interconexión y "proximidad" de seres humanos y no humanos, las dinámicas de interrelación y tensión de un rico ensamblaje social en el que el fotógrafo no impone un actante y actores sobre los otros, ni quita dignidad a cada uno de ellos.

Tal es el caso de esta bella fotografía (figura 8) donde se reformula el juego de dobles visto en las otras imágenes. A la derecha, vemos dos palmas con sus respectivos reflejos en la superficie de la charca. En el centro, está la mujer de espaldas, posiblemente contemplando el paisaje o quizá absorta en sus pensamientos. Cada una de sus manos sostiene una sandalia. Las uñas de su mano izquierda están sucias con tierra y empapadas de petróleo, como igualmente lo está la sandalia que esa mano carga. La bella pareja mano sandalia es también la pareja de la mano y la metonimia del pie, y aquella otra de una mano que dignifica y eleva el utensilio que cuelga de ella. Tenemos, entonces, la mano que cultiva la tierra y los pies que la caminan, y la sandalia suspendida que sugiere una pausa contemplativa de la mujer y de nosotros, porque, entre otras cosas, la sandalia media y hace visible la conexión entre el paisaje y la contemplación, entre el campo, el cultivar y el andar. De manera poética, Osodi hace visible un habitar como modo de ser en que cosas, tierra y cuerpos están interconectados en sus diversas temporalidades y acciones. De hecho, es notable el modo sutil como él rearticula la simetría estructurada a lo largo del horizonte en Christmas Tree // e introduce una diagonal en la que crea una resonancia entre la sandalia y la porción de tierra abajo a la izquierda, cuyo reflejo vemos en la charca. En este dinamismo, Osodi sutilmente sugiere el eventual retorno de la

Figura 9. George Osodi, "Farmland Oil Pollution". 2004

Fuente: George Osodi, https://georgeosodi photoshelter.com/index. sandalia a la tierra, la eventual reanudación de la marcha o de la tarea agrícola o doméstica.

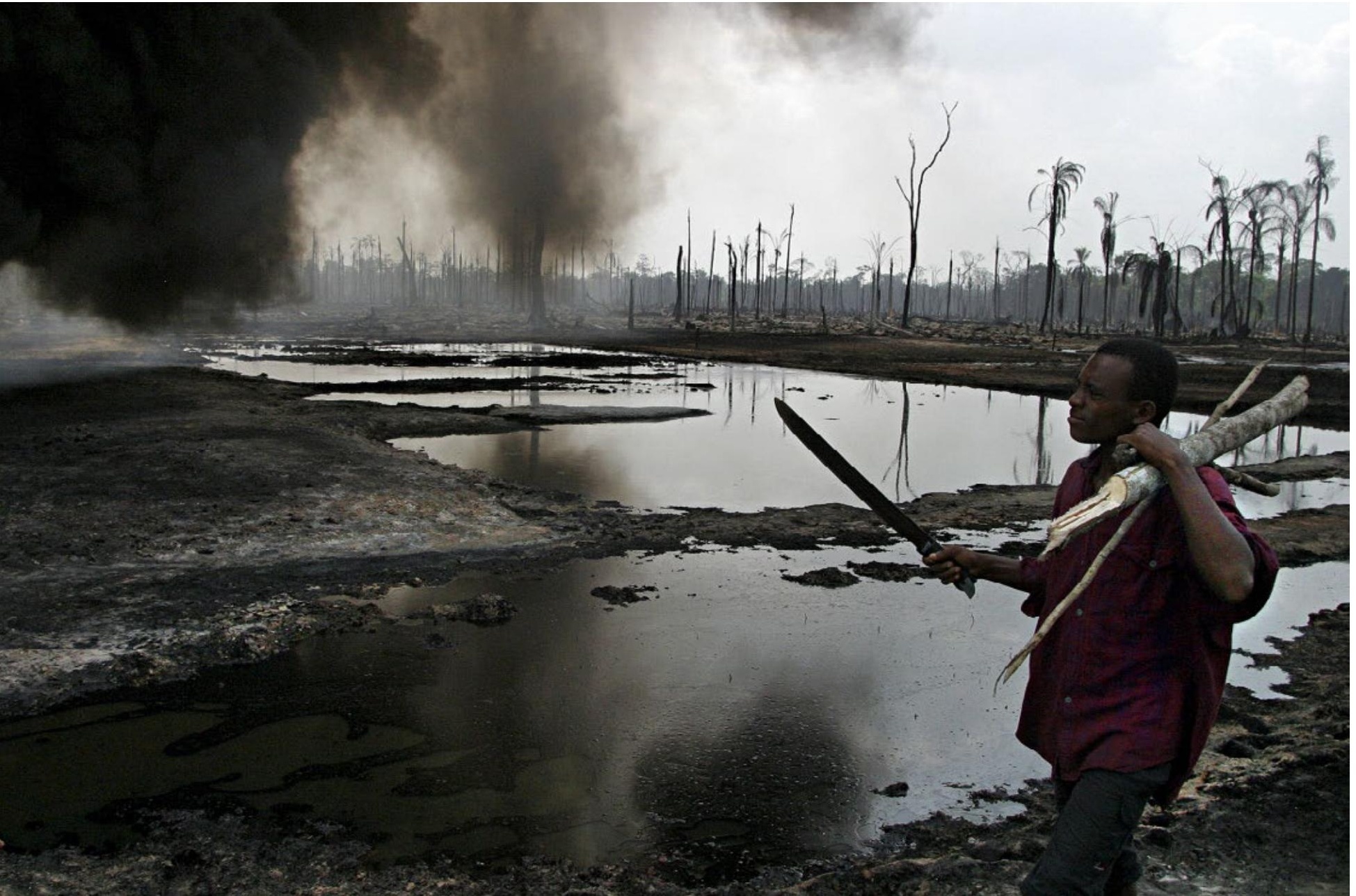


Figura 10. George Osodi, "Ogoni Boy". 2007.

Fuente: George Osodi https://georgeosodi. photoshelter.com/index.

$\Lambda$

$\Lambda$
Los actantes incluyen las "máquinas," el aire y el fuego. Son actantes en una amplia red ecológica y de una nueva cosmología. Pasemos, por ello, a otra imagen en la que vemos, en primer plano, a un hombre que carga unos leños sobre su hombre izquierdo y que lleva en su mano derecha un machete (figura 9). Él camina a lo largo del borde de una gran charca de petróleo y agua. Los derrames, huelga decirlo, han sido cosa habitual en el delta del Níger. Por ejemplo, solo en las zonas de presencia de los Ogoni, que alcanza a cubrir menos del 30 \% de la región petrolera, hubo más de 2900 derrames entre 1976 y 1991, y se regaron aproximadamente 2,1 millones de barriles de petróleo; cantidad que, según cálculos de 1996, fue el 40 \% del total de derrames de la compañía Royal Dutch Shell a nivel mundial (Crayford 1996, 42). A esos derrames que aún no han sido tratados se han sumado otros miles que han ocurrido desde entonces.

Pero volvamos a la fotografía. Al fondo, hay una zona de árboles secos y sin follaje. Un par de ellos se refleja en la gran charca. La composición de la imagen sugiere que el hombre viene de esa zona. Más al fondo se alcanza a identificar el follaje de la selva. A la izquierda, vemos una densa y llamativa nube que atrapa la luz y flota bajo. Esas conglomeraciones de aire, metales y toxinas dificultan la fotosíntesis, y al caer con la lluvia devastan la tierra, los cultivos y el bosque (Iheka 2018, 106). El machete, esa lengua metálica con el que el hombre ha tumbado y cortado un árbol, se levanta como índice que apunta a la nube, no solo recordando su presencia, sino también sugiriendo una resonancia entre el acto destructivo del hombre del delta y el "acto" destructivo del aire poluto. Además, tan oscura es la nube que ella se retrae al reflejo y permite ver con claridad las manchas de petróleo suspendidas en el agua. Estas manchas, como lo recuerda un personaje de una novela de Isidore Okpewho (1993, 146), también bloquean la luz y obstruyen la entrada y salida de aire y oxígeno, por lo que afectan la vida acuática, en particular los peces.

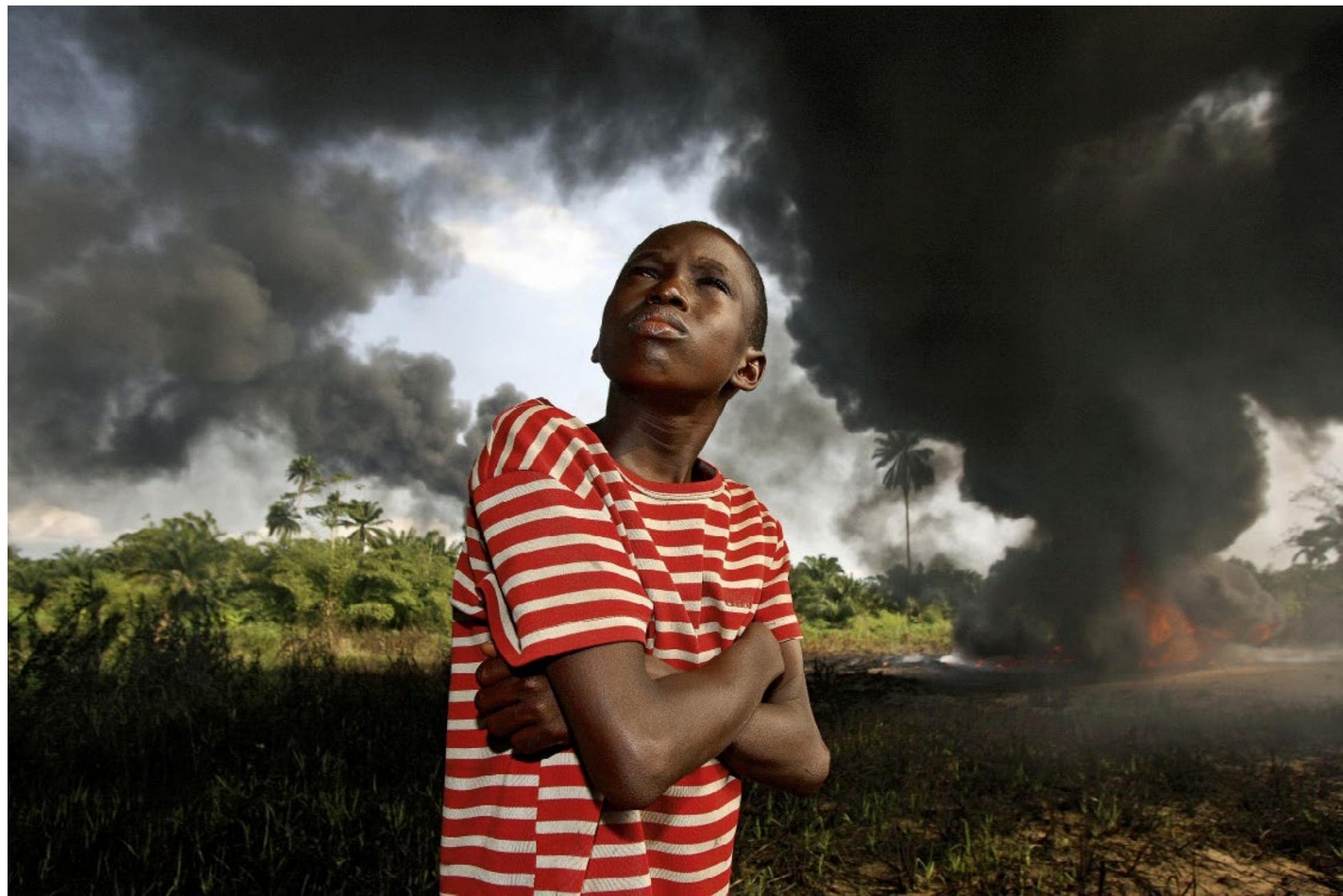


Este paisaje distópico donde la vida parece en retirada, contrasta con el paisaje utópico y paradisiaco que algunos escritores de la ecocrítica africana han descrito desde sus recuerdos o imaginación. Dicen que antes de la llegada del petróleo las personas "no carecían de nada, pescaban, cazaban, cultivaban y veían a sus hijos crecer ante ellos, felices" (Habila 2011, 42), el "aire solía ser fresco debido a la lluvia constante" y "los bosques solían tener un follaje verde intenso y exuberante, orgullo de los trópicos" (Ojaide 2006, 53). Sin la necesidad de establecer ese contraste usual en esa literatura, y sin apelar a las asunciones acríticas que adoptan un paisaje mítico y puro como referente de un pensamiento ecológico indígena en el delta del Níger (sin por ello negar que sus antepasados tenían un conocimiento ecológico ya sugerido con los tótems pero no limitado a ellos), Osodi registra poéticamente y construye imágenes que sin rodeos narran una compleja y nueva cosmología del delta.

Quiero recordar aquí que Bachelard afirmó que "ninguna sustancia de la tierra participa de modo tan inmediato de su calidad elemental, como un cielo azul" (Echandi 2004-2005, 101) y ningún objeto es más onírico que las blancas nubes en el cielo azul (Bachelard 1993, 231-232). Lo que Bachelard celebraba como imagen elemental de la existencia y de la ensoñación era el azul y la blancas condensaciones de esa gran burbuja "primigenia" de aire que nos contendría. Las suyas son imágenes de una virginal madre mítica, de un cosmos ajeno al antropoceno. Osodi, por su parte, hace patente la profunda transformación de la cosmología del delta en la paleta de cielos y nubes negros, grises, naranjas e, incluso, azules. Si para Bachelard el azul es el color de la ensoñación utilizado ahora mayoritariamente por la propaganda política conservadora a nivel global, para Osodi, y para este joven Ogoni que aparece de pie con sus brazos cruzados (figura 10), las nubes negras y tóxicas son objeto y escenario de sueño, vigilia, trauma y reflexión.

Para este joven de actitud desafiante, escuchar que el aire solía ser fresco, que el cielo era completamente azul, sería escuchar de un archivo y repertorio de generaciones anteriores. Solo parcialmente se podría suponer, como bellamente sugiere el poeta nigeriano Chi Ce, que un "evento tan casual como el vuelo de un pájaro" trajera en él "recuerdos de años lejanos" que guardamos en nuestra bolsa de recuerdos de la historia $(2008,34)$. Y, en efecto, con su ceño levemente fruncido, el joven semeja menos mirar el pasado en remembranza y más el malestar presente y hacia el porvenir.

Esta imagen recuerda lo que en varias culturas se conoce como "auspicios": escoger en el cielo una zona (que los romanos llamaron templum) en la que interpretar el porvenir en el vuelo de esas "pequeñas criaturas de Dios", de esos mensajeros divinos (Ude 2008, 213). Dicho de otro modo, la imagen es aquí doble: la fotografía-templum nos deja ver la nueva generación registrada haciendo su "auspicio". Así las cosas, este joven no semeja hacer lo que el poeta Tamure Ojaide propuso al preguntarse por "cuántas personas tienen los ojos lo suficientemente agudos como para ver a través de las espesas nubes que cubren el pasado distante" (2012, vii). Osodi más parece plantearse una doble pregunta que nutro aquí retomando la imagen con la que cerré la primera parte de este artículo, a saber, la del niño "consumido" por la lengua de fuego. La doble pregunta es ¿tiene la nueva generación los ojos lo suficientemente agudos como para ver lo que viene a través del aire poluto y las espesas nubes que cubren el presente, y tiene la fotografía una visión suficientemente aguda como para ver el porvenir a través de esas nubes y gas en combustión que parecen devorarlo? 


\section{Auspicios}

Como respuesta a los miles de derrames de petróleo en la zona Ogoni y a la exclusión racial y económica por parte del petro-Estado, en 1990, los grupos de la zona crearon el Movement for the Survival of the Ogoni People (MOSOP), un movimiento de corte no violento cuya primera acción fue la Declaración de los derechos de los Ogoni. Allí exigían que la República de Nigeria garantizara autonomía política para, entre otras cosas, darles a los Ogoni "control y uso de un porcentaje justo de los recursos económicos", el "derecho a proteger el medio ambiente y la ecología Ogoni de una mayor degradación", y permitirles superar la exclusión racial y cultural a la que estaban sometidos (Ogoni Youth Network 2019). De acuerdo con Ken Saro-Wiwa, una de las cabezas visibles del movimiento, estos derechos garantizarían "la paz, la justicia y el juego limpio y, por tanto, la estabilidad y el progreso en la nación nigeriana" $(1995,69)$.

Cuatro años después, el MOSOP organizó una protesta masiva de bloqueo de la producción de petróleo. Como respuesta, el Ejército arrasó 30 aldeas, asesinó aproximadamente 2000 personas y arrestó a manifestantes. En las confrontaciones, murieron cuatro jefes que hacían parte de una secesión conservadora dentro del movimiento, cuestión que el Estado aprovechó para arrestar a Saro-Wiwa y ocho líderes más, acusarlos de haber incitado las muertes y violencia, y finalmente sentenciarlos en un tribunal especial que nunca ofreció garantías mínimas para un juicio justo. Siguiendo la influencia del MOSOP y de Saro-Wiwa, y a menos de seis meses de la planeada transición a la democracia en mayo de 1999 que prometía un horizonte de esperanza para el nuevo siglo, más de cinco mil jóvenes lyo firmaron la Declaración de Kaiama en la que acusaban al Estado y a las compañías petroleras de "daños graves al medio ambiente, a la salud de sus pueblos", y reclamaron la propiedad de sus tierras y recursos naturales, la retirada de las fuerzas militares y la detención de las actividades petroleras en el área del estado de Bayelsa (Okonta y Douglas 2001, 146). De nuevo, el Estado reaccionó violentamente con asesinatos, saqueos y violaciones.

Como respuesta a estas condiciones de violencia y terror estatal, e incluso poco después de la Declaración Ogoni, muchos otros jóvenes criticaron la inefectividad de la propuesta no violenta de Saro-Wiwa, quien por cierto la ancló en la retórica de una nación Ogoni inexistente, y no logró presentar de manera práctica lo que habría de ser hecho en el presente para superar actitudes y prácticas de raigambre neocolonial (Caminero-Santangelo 2014, 147). Así fue como decenas de miles de jóvenes decidieron formar milicias como los Egbesu Boys (afiliados a los lyo y creados en 1990), que irónicamente han sido apoyadas por políticos que quieren manipularlas para fines electorales, aprovechando que desde 1999 los gobernadores asumieron el control directo de grandes flujos de dinero producto del petróleo. Paradójicamente, muchas de las milicias han desarrollado sus acciones violentas contra el Estado y las instalaciones y trabajadores extranjeros de las petroleras gracias al financiamiento indirecto del Estado, en lo que puede describirse más como una "democratización" de los medios de violencia (Watts 2008, 37) que una democratización de la sociedad.

Desde entonces, el delta del Níger se ha sumido en un terrible ciclo de devastación ecológica: además de los accidentes y derrames producto de la corrupción e ineficiencia, los grupos militantes han introducido la práctica de explosión de "árboles de Navidad" para detener el flujo del petróleo y forzar al Estado a aumentar la inversión y reconocer a las comunidades control y derechos sobre la sangre negra del petróleo. Esta práctica conocida como "ecoterrorismo", que ha incluido el secuestro de trabajadores foráneos, ha sido criticada por muchos y defendida por otros quienes señalan que, mientras a los terroristas no les interesa la vida, "las acciones de los activistas ambientalistas están motivadas por su carácter sagrado" (Sumner y Wiedman 2013, 870). De hecho, no sobra recordar que el nombre de la milicia Egbesu Boys hace referencia a Egbesu como "poder defensivo y ofensivo del Ser Supremo utilizado para defender las leyes divinas de la naturaleza y para proteger del mal a los rectos o justos" (Bayelsa State Union 2019). 


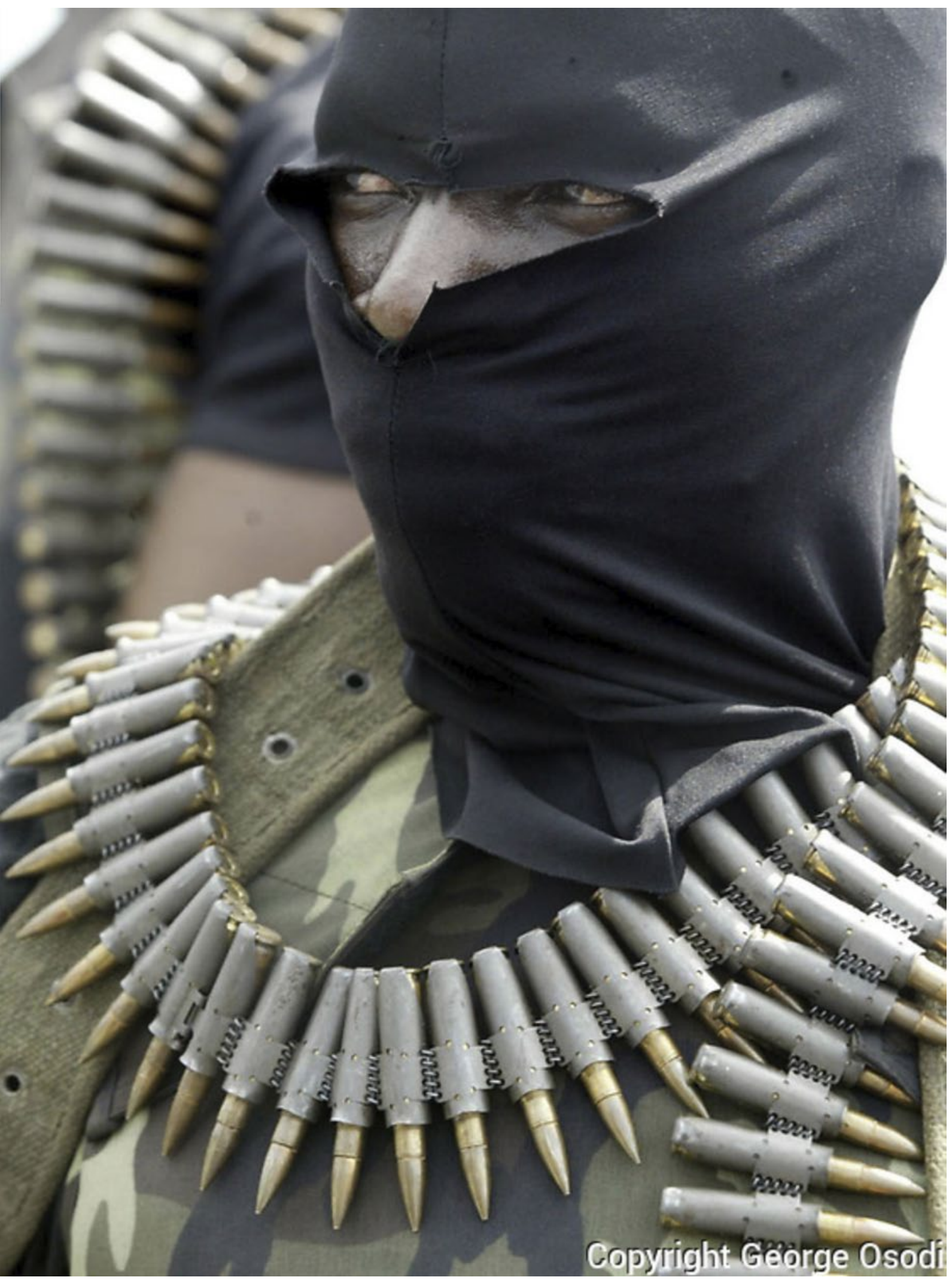


Figura 12. George Osodi, "Delta Conflict". 2004.

Fuente: George Osodi, https://georgeosodi. photoshelter.com/index.

$\Lambda$

$\Lambda$
Se entiende, entonces, que este ciclo de devastación ecológica ha sido también de devastación social, y que el delta del Níger se ha convertido en un "gigante reservorio de ira y disidencia" (Caminero-Santangelo 2014, 137), donde figura un amplio espectro de fuerzas e intereses identificados con grupos sociales no violentos, movimientos políticos, milicias étnicas y milicias separatistas (que algunas veces coinciden), paramilitares y fuerzas del Estado, que evidencian las dificultades existentes para hablar de una supuesta "nación nigeriana". Una de las milicias es la Movement for the Emancipation of the Niger Delta (MEND), creada en 2004 y hasta hoy el grupo militar rebelde más grande de todos. Reconocidos por sus máscaras negras y rifles de asalto Kalashnikov, patrullan los caños del delta en lanchas rápidas que casi vuelan sobre el agua. Osodi ha retratado un militante de una manera muy especial, mostrando la cinta de municiones que da vuelta sobre sus hombros como si fuese una suerte de collar en el que los proyectiles reemplazaron las semillas y huesos, y un rostro humano que con la máscara pareciera transformarse en el de un ave (figura 11).

Esa máscara, que sin duda infunde miedo, parecería sugerir una transformación de la máscara y tocado de la reina Idia, y anunciar a esas figuras del MEND como unas que tienen un nuevo poder de canalización y direccionamiento del flujo petrolero para los hijos del delta. Con toda seguridad, estas "aves" han encarnado para algunos lo que William Blake describió como "el aire libre personificado". Son "aves" que vuelan en sus rápidas lanchas circundando islas, son promesa de cambio y augurio de una transformación esperada de la que ellos encarnan su rostro violento. ¿Serán esas figuras las "aves" que se manifiestan al joven Ogoni?

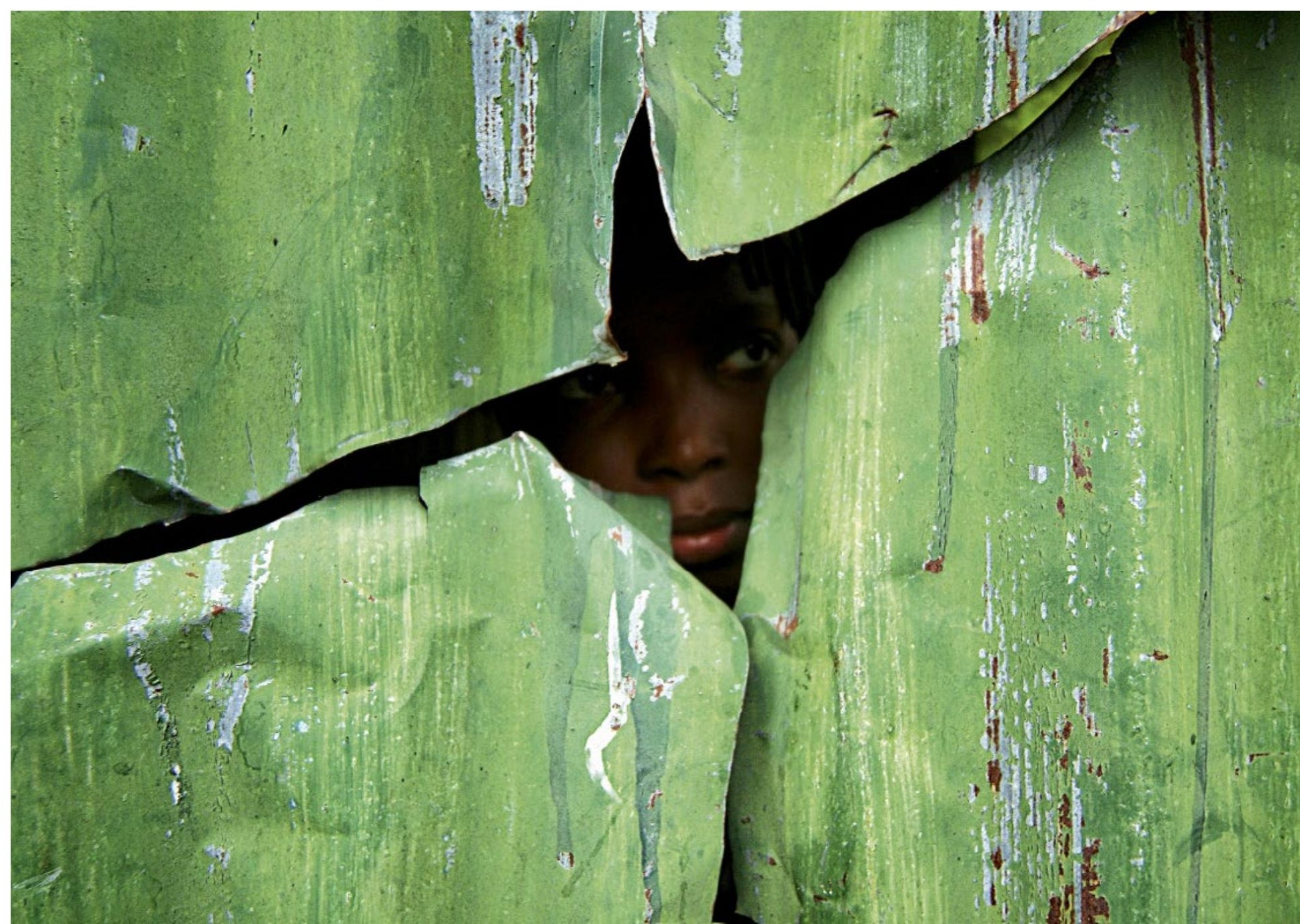


Parte del esfuerzo de Osodi por formular y responder a la doble pregunta con la que cerré la segunda parte de este artículo, se anuncia en la fotografía del joven, de este miliciano, y de una tercera con la que cierro este artículo: la de una niña o un niño que mira a través de los cortes hechos en una lata verde (figura 12). Estos cortes, producto del impacto de machetes, ha resultado en la sugerente forma de un ave en pleno vuelo. Contrastada con la inmediatamente anterior, revela una máscara que no transforma el rostro en uno de un "ave", sino que revela la forma del ave teniendo como "contenido" su rostro.

Durante el desarrollo de esta poética serie realizada pocos años después de la llegada de la democracia a Nigeria, al menos en su formalidad estatal, Osodi da cuenta, no solo de la magnitud de los daños ecológicos en el delta, sino también de cómo las dinámicas de violencia y devastación son más propias de una compleja red de fuerzas, actores, actantes y deseos que no pueden achacarse sin más al Estado, como lo creyeron generaciones anteriores, entre ellos, el poeta Ojaide. Y ante la posibilidad, como lo hiciera este, de concebir la situación y debacle social del delta como un "huracán de categoría 5" que extrae su fuerza de la condensación y del enrarecimiento del aire, y que arrasa con todo (Ojaide 2015, 19), Osodi parece apuntar a una crítica, pero igualmente paciente y esperanzada actitud en la que actores y actantes tienen siempre un aire de dignidad. De hecho, la imagen que muestra el rostro de una niña o un niño como contenido del "ave en vuelo" y que Osodi titula de una manera que parece recoger buena parte de las paradojas del conflicto del delta, se antoja como otro auspicio fotográfico suyo, uno en el que la esperanza está en las nuevas generaciones que logren vestir, por así decirlo, la máscara del poder — no siempre exento de violencia- de canalización y direccionamiento del flujo petrolero para el bien de todas las complejas e increíblemente ricas culturas nigerianas de la región. La esperanza está en las nuevas generaciones que sean capaces de volar, de aceptar la realidad y a la vez asumir la libertad en medio de la debacle como vuelo dinámico, digno y responsable.

1. Las traducciones son mías.

2. "La ideología del comunalismo espiritual africano [...] no es socialismo ni welfarismo [i. e., capitalismo]" (Onwuachi 1977, 16).

3. Me refiero a la Convención sobre las medidas que deben adoptarse para prohibir e impedir la importación, la exportación y la transferencia de propiedad ilícitas de bienes culturales de 1970. En 1977, ningún Estado europeo la había ratificado (Robinson 1977, 68)

4. Changó, en los Yoruba, es el orishá de la justicia, de los rayos, del trueno y del fuego. 
Apter, Andrew. 2005. The Pan-African Nation: Oil and the Spectacle of Culture in Nigeria. Chicago: The University of Chicago Press.

Bachelard, Gastón. 1966. Psicoanálisis de fuego. Madrid: Alianza. . 1993. El aire y los sueños. México: Fondo de Cultura Económica.

Bayelsa State Union. 2019. "What is Egbesu?". Consultado: 20 de septiembre de 2019. https://web.archive.org/web/20121014192943/ http:/www.bayelsa.org.uk/main/what-is-egbesu/

Bhabha, Homi, ed. 1990. Nation and Narration. Londres: Routledge.

Bueger, Christian y Jan Stockbruegger. 2017. "Actor-Network Theory: Objects and Actants, Networks and Narratives". En Technology and World Politics: An Introduction, editado por Daniel R. McCarthy, 4259. Abingdon: Routledge.

Caminero-Santangelo, Byron. 2014. Different Shades of Green: African Literature, Environmental Justice, and Political Ecology. Charlottesville: University of Virginia Press.

Ce, Chin. 2008. "Introduction: The Art of Younger Poets". En New Voices. A Collection of Recent Nigerian Poetry, editado por Gloria Monica Emezue, 15-39. Garcena: The African Books Network.

Clark, John Pepper. 2020. "Night Rain". Consulta: 31 de marzo de 2020. https:// allpoetry.com/poem/10602495-Night-Rain-by-John-Pepper-Clark

Crayford, Steven. 1996. "Ogoni Uprising". Africa Today 43 (2): 183-197.

Echandi, Marcela. 2004-2005. "El aire como elemento fundamental de la imaginación en el aire y los sueños de Gaston Bachelard". Revista Estudios 18-19: 95-103.

Festac '77 Visitors Guide to the Festival. 1977. Lagos: International Secretariat.

Gaunt, Philip. Festac '77 - Festival de Lagos. 1977; Unesco TV/Nigerian National Broadcasting Commission, 1997.

Gouveia, Sara de. (Counter) Festac '77 '77. 2014; Cape Town: Chimurenga, 2016.

Habila, Helon. 2011. Oil on Water. New York: W. W. Norton \& Company.

Hawkes, Terence. 1977. Structuralism and Semiotics. Berkeley: University of California Press.

Iheka, Cajetan. 2018. Naturalizing Africa: Ecological Violence, Agency, and Postcolonial Resistance in African Literature. Cambridge: Cambridge University Press.

Kaplan, Flora Edouwaye S. 2008. "Idia, Queen Mother". En The Oxford Encyclopedia of Women in World History. Vol 1: Abayomi-Czech Republicb, editado por Bonnie G. Smith, 527-528. Oxford: Oxford University Press.

LaGamma, Alisa. 2012. Heroic Africans: Legendary Leaders, Iconic Sculptures. Nueva York: The Metropolitan Museum of Art.

Latour, Bruno. 2005. Reassembling the Social: An Introduction to ActorNetwork Theory. Oxford: Oxford University Press.

Loomba, Ania. 2005. Colonialism/Postcolonialism. Londres: Routledge.
Malinowski, Bronisław. 1948. Magic, Science and Religion and other Essays. Boston: Beacon Press.

Mbiti, John. 1977. "African oral Literature”. En Festac' 77, 96-97. Lagos: Africa Journal Limited/International Festival Committee.

NOSDRA (National Oil Spill Detection \& Response Agency). 2019. "Nigerian Oil Spill Monitor". Consultado: 1 de agosto de 2019. https://nosdra.gov.ng

OPEC (Organization of the Petroleum Exporting Countries). 2019. "Nigeria Facts and Figures". Consultado: 20 de septiembre de 2019. https://www.opec.org/opec_web/en/about_us/167.htm

Ogoni Youth Network. 2019. "Ogoni Bill of Rights". Consultado: 12 de octubre de 2019. shorturl.at/kqJ05

Ojaide, Tanure. 2006. The Activist. Lagos: Farafina.

Ojaide, Tanure. 2012. Stars of the Long Night. Lagos: Malthouse Press.

Ojaide, Tanure. 2015. The Tale of the Harmattan. Ibadan: Kraft Books.

Onwuachi, P. Chike. 1977. "African Identity and Ideology". En Festac' 77, 1617. Lagos: Africa Journal Limited/International Festival Committee.

Okpewho, Isidore. 1993. Tides. Londres: Longman.

Oriji, John N. 2009. "Transformations in Igbo Cosmology during Slavery: A Study of the Geneses of Place-Names, Totems \& Taboos". Cahiers d'études africaines 196: 953-967.

Okonta, Ike y Oronto Douglas. 2001. Where Vultures Feast: Shell, Human Rights and Oil in the Niger Delta. San Francisco: Sierra Club.

Osodi, George. 2003-2007. "Oil Rich Niger Delta". Consultado: 2 de septiembre de 2019. https://georgeosodi.photoshelter.com/index

Paoletti, Giulia. 2009. "Review: Paradise Lost: Revisiting the Niger Delta". African Arts 42: 80-88.

Peter, Magelah. 2007. “Totem”. Consultado: 21 de mayo de 2007. https:// editors.eol.org/eoearth/wiki/Totem_(Environmental__ \%26 Earth_Science)

Radcliffe-Brown, Alfred. 1952. Structure and Function in Primitive Society. Glencoe: The Free Press.

Raji, Remi. 2005. Lovesong for My Wasteland. Ibadan: Bookcraft.

Robinson, Alma. 1977. "African Art in Foreign Hands". En Festac '77, 5659. Lagos: Africa Journal Limited/International Festival Committee.

Saro-Wiwa, Ken. 1995. A Month and A Day: A Detention Diary. Londres: Penguin Books.

Senghorel, Leopold S. 1977. "Black Culture". En Festac '77, 12-13. Lagos: Africa Journal Limited/International Festival Committee.

Sissako. Abderrahmane. La vie sur terre. 1998; Mali: Haut et Court, 1998.

Sumner David T. y Lisa M. Wiedman. 2013. “Eco-terrorism or Ecotage: An Argument for the Proper Frame". ISLE: Interdisciplinary Studies in Literature and Environment 20 (4): 855-876. 
Thurber, Mark. 2019. "Gas Flaring: Why Does It Happen and What Can Stop It?". Energy forg Growth Hub (blog), 4 de febrero, https://www. energyforgrowth.org/memo/gas-flaring-why-does-it-happen-andwhat-can-stop-it/

Ude, King Agwu. 2008. "Birds of the Air". En New Voices: A Collection of Recent Nigerian Poetry, editado por Gloria Monica Emezue. Garcena: The African Books Network.

Watts, Michael. 2008. "Imperial Oil: The Anatomy of a Nigerian Oil Insurgency". Erkunde 62 (1): 27-39.

Wu, Chengyi Coral. 2016. "Towards an African-Focused Ecocriticism: The Case of Nigeria". Tesis de doctorado, University of Nevada. 